\title{
PENGARUH KETERAMPILAN KEWIRAUSAHAAN DAN KARAKTERISTIK INDIVIDU TERHADAP KEBERHASILAN USAHA PADA USAHA MIKRO DAN KECIL DI PERUMAHAN INDOGREEN, CITEUREP BOGOR
}

\author{
${ }^{1)}$ Dasmansyah Adyas, ${ }^{2)}$ Rudy Kurniawan \\ ${ }^{1)}$ Dosen Program Studi Manajemen, STIE Dewantara \\ Jl. Raya Pemda Bojong Depok Baru III, Karadenan, Cibinong, Bogor, Jawa Barat 16913,Indonesia \\ Email: dasmansyah.adyas@dewantara.ac.id \\ ${ }^{2)}$ Alumni Program Studi Manajemen, STIE Dewantara \\ Jl. Raya Pemda Bojong Depok Baru III, Karadenan, Cibinong, Bogor, Jawa Barat 16913, Indonesia \\ Email: rudyragnell@gmail.com
}

\begin{abstract}
This study aims to determine the effect of entrepreneurial skills and individual characteristics on the success they manage a business, especially small and micro entrepreneurs who open a business in Indogreen housing, Citeurep Bogor District. In this research the object is the entrepreneurs who numbered 50 people with saturated sample method. The data used in this study is the primary data derived from the questionnaire distribution. While the data analysis using Multiple Regression analysis technique.The findings of this study are the two variables tested both partially and simultaneously. In the test terminated $R$ square value there are results of 0.670 or $67 \%$ of business success can be explained by entrepreneurial skills and the remaining individual characteristics of $33 \%$ by other variables not examined.
\end{abstract}

Keywords: Entrepreneurship Skills, Individual Characteristics.

\begin{abstract}
ABSTRAK
Penelitian ini bertujuan untuk mengetahui pengaruh Keterampilan kewirausahaan dan karakteristik individu pada keberhasilan mereka mengelola suatu usaha, khususnya para pengusaha kecil dan mikro yang membuka usaha di perumahan Indogreen, Citeurep Kabupaten Bogor. Dalam penelitian ini yang menjadi objek adalah para wirausahawan yang berjumlah 50 orang dengan metode sample jenuh. Data yang digunakan dalam penelitian ini adalah data primer yang berasal dari penyebaran kuestioner. Sedangkan analisa data menggunakan tehnik analisa Regresi Berganda. Hasil temuan dari penelitian ini kedua variabel yang diujikan berpengaruh baik secara parsial maupun simultan. Pada uji diterminasi nilai $\mathrm{R}$ square terdapat hasil sebesar 0,670 atau $67 \%$ keberhasilan usaha dapat dijelaskan oleh keterampilan kewirausahaan dan karakteristik individu sisanya sebesar 33\% oleh variabel lain yang tidak diteliti.
\end{abstract}

Kata kunci: Keterampilan Kewirausahaan, Karakteristik Individu.

\begin{tabular}{ll}
\hline 1. PENDAHULUAN & istilah mikro kecil maupun menengah \\
Sangat menarik untuk mengetahui & (UMKM). Bagaimana manusia tersebut \\
bagaimana manusia sebagai makhluk & berhasil mempertahankan usahanya, \\
individu dalam kesehariannya untuk & pengetahuan seperti apa yang dibutuhkan, \\
menjaga keberlangsungan dan kebutuhan & sifat atau karakter yang bagaimana yang \\
hidup adalah dengan melakukan berbagai & disyaratkan. \\
usaha atau berbisnis. Dalam menjalankan & Jika merujuk pada pandangan ilmu \\
usahanya dengan baik dengan modal dan & ekonomi seorang pengusaha atau \\
pengetahuan yang minim, kemauan keras & wirausahawan adalah seseorang yang \\
dan sifat yang pentang menyerah para & mengusahakan sumber daya produksi yang \\
pengusaha berhasil mempertahan usahanya. & terdiri dari tanah, modal, tenaga kerja, \\
Usaha yang dijalankan dikenal dengan & keterampilan kewirausahaan juga tehnologi
\end{tabular}


untuk mendapatkan laba atau keuntungan, dengan cara menggunakan atau mengubah faktor-faktot tersebut menjadi barang atau jasa yang dibutuhkan oleh konsumen.

Untuk menjalankan usahanya hingga berhasil, sesorang dituntut untuk mempunyai bekal ilmu pengetahuan dan keterampilan dalam bidangnya. Jadi seseorang yang memutuskan untuk menjadi wirusahawanpun dituntut untuk mebekali dirinya dengan pengetahuan dan keterampilan kewirausahaan. Tentu saja pengetahuan tentang kewiraausahan tidaklah cukup untuk menjadikan seseorang berhasil dalam menjalankan usahanya harus juga harus ditunjang oleh sifat atau karakter yang dimiliki orang tersebut.

Karakter seperti apakah yang dibutuhkan seseorang dalam menjalankan usahanya. Jika merujuk pada pendapat Peter F Drucker (1994, dalam Suryana 2013) seorang wirausahawan adalah orang mempunyai sifat atau karakter yaitu sesorang mempunayi kemauan keras dalam mewujudkan gagasan yang inovatif kedunia usaha.selanjutnya Peter F. Drucker menyatakan seseorang yang mampu menciptakan sesuatu yang baru dan berbeda dan bisa memenuhi kebutuhan atau keinganan orang lain. Penelitian ini berfokus untuk menguji apakah para pengusaha atau wirausahaan khususnya pengusahan mikro dan kecil yang berada diperumahan Indogreen Citeurep Bogor, juga dalam menjalankan usahanya sehingga berhasil berkembang atau bertahan, memiliki keterampilan kewirausahaan dan karakteristik individu sebagai seorang pengusaha.

Penelitian ini berfokus pada permasalahan Keterampilan Kewirausahaan dan Karakteristik Individu terhadap KerberhasilanUsaha pada Usaha Mikro dan Kecil (UMK) di Perumahan Indogreen, Citeureup - Bogor. Sedangkan permasalahan yang akan diteliti dapat dirumusakan :
1. Bagaimana pengaruh keterampilan kewirausahaan terhadap keberhasilan usahapada usaha mikro dan kecil di Perumahan Indogreen, Citeureup Bogor?

2. Bagaimana pengaruh karakteristik Individu terhadap keberhasilan usaha pada usaha mikro dan kecil di Perumahan Indogreen, Citeureup Bogor?

3. Bagaimana pengaruh keterampilan kewirausahaan dan karakteristik individu secara bersama-sama/simultan terhadap keberhasilan usaha pada usaha mikro dan kecil di Perumahan Indogreen, Citeureup - Bogor?

\section{TINJAUAN PUSTAKA}

\subsection{Pengertian Kewirausahaan}

Kewirausahaan adalah disiplin ilmu yang mempelajari tentang nilai, kemampuan, dari perilaku seseorang dalam menghadapi tantangan hidup untuk memperoleh peluang dengan berbagai risiko yang mungkin dihadapi (Sudaryono, 2010:1). Enam hakikat penting kewirausahaan:

a. Kewirausahaan adalah nilai yang diwujudkan dalam perilaku yang dijadikan dasar sumber daya, tenaga penggerak, tujuan, siasat, kiat, proses, dan hasil bisnis.

b. Kewirausahaan adalah kemampuan menciptakan sesuatu yang baru dan berbeda.

c. Kewirausahaan adalah proses penerapan kreativitas dan inovasi dalam memecahkan persoalan dan menemukan peluang untuk memperbaiki kehidupan atau usaha.

d. Kewirausahaan adalah nilai yang diperlukan untuk memulai dan mengembangkan usaha.

e. Kewirausahaan adalah proses dalam mengerjakan sesuatu yang 
baru dan bermanfaat serta bernilai lebih.

f. Kewirausahaan adalah usaha menciptakan nilai tambah dengan jalan mengkombinasikan sumbersumber melalui cara-cara baru dan berbeda untuk memenangkan persaingan. Nilai tambah tersebut dapat diciptakan dengan cara mengembangkan teknologi dan ilmu pengetahuan, menghasilkan barang dan jasa sehingga lebih efisien memperbaiki produk dan jasa yang sudah ada, dan menemukan cara untuk memberikan kepuasan kepada konsumen (Sudaryono dkk, 2011:41).

\subsection{Keterampilan Kewirausahaan :}

Dalam mengembangkan usaha hingga berhasil seorang wirausahawan tidak saja harus memiliki pengetahuan yang cukup juga keterampilan. Suryana (2013: 89) ketrampilan yang harus dimiliki seorang wirausahaan adalah :

1. Technical skill, keterampilan untuk melakuka tugas tugas khusus seperti mengoperasikan computer, terampil menggambar.

2. Human relation skill terampil dalam berhubungan dengan sesama manusia.

3. Conseptual skill, mampu dan terampil dalam membuat dan merumuskan sebuah konsep yang bersifat abstrak.

4. Decition making skill, mempunyai keterampilan dalam mengambil keputusan, terutama disaat yang keritis.

5. Time management skill, keterampilan untuk mengatur waktu sehingga produktif.

\subsection{Pengertian Karakteristik Individu}

Setiap manusia mempunyai karakteristik individu yang berbeda-beda antara yang satu dengan yang lainnya. Di mana dapat dijelaskan oleh beberapa pendapat dari berbagai ahli sebagai berikut: Rivai (2006:67) menyatakan bahwa karakteristik individu adalah ciri-ciri khusus, sifat-sifat kejiwaan, akhlak atau budi pekerti yang dimiliki seseorang yang membedakannya dengan orang lain.

\subsection{Dimensi Karakteristik Individu}

Menurut Ardana

(2009:31)

karakteristik individu meliputi beberapa hal yang membedakan antara satu sama lain, seperti :

a. Ciri Biografis Menurut Robbins (2008:63), karakteristik biografis, yaitu: Umur, Jenis Kelamin, dan status perkawinan, sesuatu yang objektif dan mudah diperoleh dari catatan pribadi.

b. Kepribadian merupakan perbedaan karakteristik individu. Kepribadian dapat juga dikatakan kombinasi antara seperangkat fisik dan karakteristik mental seseorang.

Kepribadian dapat dilihat dari perilaku individu, seperti bagaimana cara seseorang berbicara, bertindak dan melakukan sesuatu. Tampubolon (2008:28) menyatakan bahwa "Kepribadian adalah gambaran profil seseorang atau kombinasi dari karakteristik disertai keunikan seseorang secara alamiah yang berinteraksi dengan lainnya". Hasibuan (2009:138) menyatakan bahwa "Kepribadian adalah serangkaian ciri yang relatif tetap dan sebagian besar dibentuk oleh faktor keturunan, sosial, kebudayaan, dan lingkungan".

c. Persepsi Persepsi merupakan proses kognitif yang mencakup penafsiran objek-objek, simbol-simbol dan orangorang, dipandang dari sudut pengalaman penting, dimana seorang individu memberikan arti kepada lingkungan. Masing-masing orang memberi artinya sendiri terhadap stimuli atau gambaran hasil panca indera, maka dapat dikatakan bahwa 
individu yang berbeda "melihat" hal yang sama dengan cara yang berbeda. Ivancevich et al (2006:116), "Proses dimana seorang individu memberikan arti pada lingkungan. Hal tersebut melibatkan pengorganisasian dan penerjemahan berbagai stimulus menjadi suatu pengalaman psikologis". Sedangkan, Tampubolon (2008:63): "Persepsi dapat didefinisikan sebagai gambaran seseorang tentang sesuatu objek yang menjadi fokus permasalahan. Persepsi bagi pribadi diri sendiri meliputi sikap, motif, kepentingan atau minat, pengalaman masa lalu dan pengharapan (ekspektasi). Selain itu faktor seperti waktu, keadaan/tempat kerja dan keadaan sosial serta decision making juga turut andil dalam persepsi bagi pribadi diri sendiri.

d. Sikap Ivancevich et,al (2006:87) Sikap (Attitude) merupakan keadaan mental yang dipelajari dan diorganisasikan melalui pengalaman, menghasilkan pengaruh spesifik pada respons seseorang terhadap orang lain, objek, situasi yang berhubungan. Tampubolon (2008:34) Sikap adalah kesiapan mental untuk merespon sesuatu, baik yang negatif maupun yang positif. Robbins (2007:93) adalah pernyataan-pernyataan atau penilaianpenilaian evaluatif berkaitan dengan obyek, orang, atau peristiwa. Sikap mempunyai tiga komponen utama:

1. Pikiran (Kognisi) dari sikap terdiri dari persepsi, opini, dan keyakinan individu. Keyakinan seseorang mengenai suatu objek tentang apa yang telah dilihat atau di ketahuinya, yang memberinya ide tentang karakteristik objek tersebut. Hal tersebut merujuk pada proses pemikiran dengan penekanan khusus terhadap rasionalitas dan logika.
2. Emosi (Afeksi) merupakan komponen emosional dari sikap. Afeksi merupakan bagian dari sikap yang berhubungan dengan perasaan tertentu pada orang, kelompok, atau situasi.

3. Perilaku (Behavior) adalah suatu maksud untuk berperilaku dengan suatu cara tertentu, yang ada dalam diri seseorang berkaitan dengan objek sikap yang dipengaruhinya.

\subsection{Pengertian Keberhasilan Usaha}

Seorang pengusaha yang berhasil adalah pengusaha yang mendapatkan keuntungan dari usaha yang ia jalankan serta berhasil menjaga keberlangsungan usahanya dalam jangka waktu yang relatif lama. Demikian pula jika merujuk pada penelitian (Adyas, 2015) bahwa keberhasilan usaha dipengaruhi keperibadian dan pengalaman dari pengusaha.

\subsection{Pengertian Usaha Mikro, Kecil dan Menegah (UMKM)}

Banyak definisi tentang usaha mikro, kecil dan menengah yang dikemukakan oleh beberapa lembaga atau instansi bahkan UU. Undang-undang terbaru yang dikeluarkan pemerintah tentang usaha mikro, kecil dan menengah adalah UU No. 20 Tahun 2008. Menurut UU No.20 tahun 2008 Pasal 1 yang secara garis besar dapat disimpulkan sebagai berikut:

a. Usaha Mikro adalah usaha perorangan seperti yang diatur dalam undangundang.

b. Usaha yang dimiliki secara pribadi dan bukan merupakan usaha yang berupa cabang atau anak perusahaan. Dimana kekayaan ayng dimiliki sebagai yang diatur dalam undang-undang.

c. Demikian pula usaha menengah adalah usaha yang dimiliki sendiri, yang tidak berhubungan baik langsung maupun tidak langsung dengan perusahaan induk. Dimana jumlah kekeyaan 
maupun hasil usaha pertahunnya sesuai dengan UU (UMKM). Dalam UndangUndang ini.

\subsection{Kriteria Usaha Mikro, Kecil dan Menegah (UMKM)}

Mengacu pada UU No. 20 tahun 2008 yang dimaksud dengan usaha mikro adalah pengusaha yang mempunyai modal atau kekayaan bersih paling banyak lima puluh juta rupiah dengan omzet tahunan paling banyak tiga ratus juta rupiah, sedangkan yang dimaksud dengan usaha kecil adalah pengusaha yang mempunyai kekayaan bersih lebih dari lima puluh juta rupiah dengan maksimal lima ratus juta rupiah dengan omset tahunan dua miliar lima ratus juta rupiah.

\subsection{Kerangka Pemikiran}

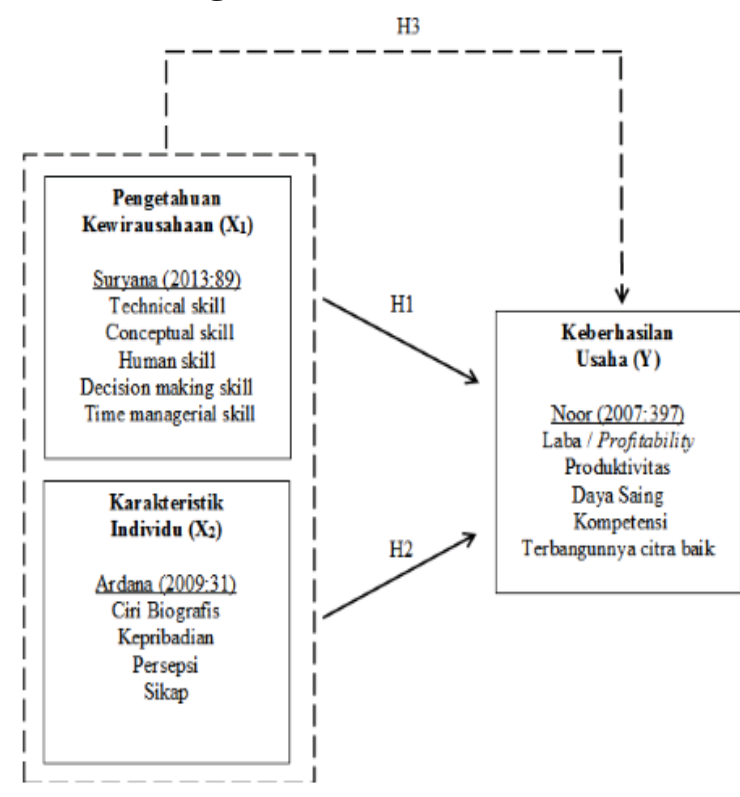

\section{Gambar 1. Kerangka Pemikiran}

\subsection{Hipotesis}

Penelitian ini nantinya berguna untuk menegaskan suatu teori dan dapat diterapkan dalam keadaan nyata. Berdasarkan masalah yang diangkat dalam penelitian ini yakni mengenai penelitian pengaruh keterampilan berwirausaha dan karakteristik individu terhadap keberhasilan usaha pada usaha mikro kecil di Perumahan Indogreen Citereup - Bogor, maka berikut hipotesisyang diajukan dalam penelitian ini

$\mathrm{H}_{0}$ : Tidak adanya pengaruh secara silmutan dan parsial antara pengetahuan kewirausahaan dan karakteristik individu terhadap keberhasilan usaha pada usaha mikro dan kecil di Perumahan Indogreen, Citereup Bogor.

$\mathrm{H}_{1}$ : Adanya pengaruh pengetahuan kewirausahaan terhadap keberhasilan usaha pada usaha mikro dan kecil di Perumahan Indogreen, Citeureup Bogor.

$\mathrm{H}_{2}$ : Adanya pengaruh karakteristik individu terhadap keberhasilan usaha pada usaha mikro dan kecil di Perumahan Indogreen, Citeureup - Bogor.

$\mathrm{H}_{3}$ : Adanya pengaruh secara simultan antara pengetahuan kewirausahaan dan karakteristik individu terhadap keberhasilan usaha pada usaha mikro dan kecil di Perumahan Indogreen, Citeureup - Bogor.

\section{METODE PENELITIAN}

Jenis penelitian yang penulis ambil merupakan jenis penelitian yang sifatnya kausalitas yakni sesuatu bersifat sebab akibat dengan metode kuantitatif. sebagaimana menurut Sugiyono (2014:8).

\subsection{Variabel Penelitian}

Variabel yang menjadi variabel bebas yaitu keterampilan kewirausahaan (X1) dan karakteristik individu (X2) sedangkan variabel terikatnya adalah keberhasilan usaha (Y). Penelitian ini dilakukan di Perumahan Indogreen RW 04 Desa Gunung Sari Kecamatan Citeureup Kabupaten Bogor. Adapun penelitian ini dilakukan selama 4 bulan yaitu sejak bulan Oktober 2017 s.d Januari 2018. 


\subsection{Objek Penelitian}

Objek dalam penelitian ini adalah pemilik usaha mikro dan kecil yang berlokasi di Perumahan Indogreen RW 04 Desa Gunung Sari Kecamatan Citeureup Kabupaten Bogor.

\subsection{Populasi dan Sampel}

Populasi dari penelitian ini adalah pemilik usaha mikro dan kecil yang berlokasi di Perumahan Indogreen RW 04 Desa Gunung Sari Kecamatan Citeureup Kabupaten Bogor yang berjumlah 50 pengusaha atau wiraswatawan.

Teknik sampling yang diuraikan dalam penelitian ini adalah teknik sampling jenuh (sensus). Sampling jenuh adalah teknik penentuan sampel bila semua anggota populasi digunakan sebagai sampel. Istilah lain sampling jenuh adalah sensus,dimana semua anggota populasi dijadikan sebagai sampel. Sugiyono (2016:85).

\subsection{Teknik Pengumpulan Data}

Pengumpumpulan data dikumpulkan dengan penyebaran kuesioner kepada responden yaitu pemilik usaha Mikro dan Kecil di Perumahan Indogreen, Citeurep Bogor.

Teknik Analisis Analisis data dalam penelitian ini meliputi : Uji Kualitas Data Uji Validitas, Uji Reliabilitas, Uji Korelasi, Uji Asumsi Klasik, Uji Normalitas , Uji Multikolinieritas, Uji Heteroskedastisitas, Analisis Regresi Linier Berganda ( $\mathrm{Y}=\mathrm{a}+$ $\left.b_{1} X_{1}+b_{2} X_{2}+e\right)$ Uji Kelayakan Suatu Model, Uji Signifikansi Parsial (Uji T), Uji Signifikansi Simultan (Uji F), Koefisien Determinasi $\left(R^{2}\right)$.

\section{HASIL DAN PEMBAHASAN}

\subsection{Hasil Penelitian}

Uji Kualitas Data, Uji Validitas, Suatu kuesioner dikatakan valid jika pertanyaan pada kuesioner mampu untuk mengungkap sesuatu yang akan diukur oleh kuesioner tersebut. diperoleh $\mathrm{r}$ tabel sebesar 0,278.
Hasil uji validitas pada pengujian ini, mendapatkan hasil seluruh pertanyaan dalam kuesioner yang berjumlah 40 (empat puluh pertanyaan) dinyatakan valid, karena $r$ tabel $(0,278)<$ dari $r$ hitung $r$ hitung yang terkecil 0,361 pada pertanyaan no.5 di variabel X1.

Pengujian reliabilitas dalam penelitian ini menggunakan rumus Alpha.

Hal ini menunjukkan bahwa semua variabel mempunyai koefisien Alpha yang cukup besar yaitu diatas 0,60 dimana Cronbach Alpha untuk keterampilan $(0,805)$, untuk Karakteristik $(0,872)$ sedangkan untuk keberhasilan usaha $(0,888)$ atau dapat dikatakan semua item indikator masingmasing variabel dari kuesioner adalah reliabel. Sehingga untuk selanjutnya itemitem pada masing-masing variabel tersebut layak digunakan sebagai alat ukur.

\subsection{Karakteristik Responden}

Berikut ini adalah tabulasi mengenai karakteristik responden yang berjumlah 50 orang, didistribusikan sebagai berikut untuk jenis kelamin laki-laki terdiri dari 33 orang (66\%), wanita 17 orang (34\%), sedangkan usia antara 20-35 tahun 8 orang, 36 -50 tahun 33 orang dan diatas 50 tahun 9 orang, pendidikan tertinggi dari responden sarjana sebesar 9 orang dan terendah SD 4 orang, lamanya usaha 1-5 tahun 17 orang (34\%), 6-10 tahun 13 orang (26\%), diatas 10 tahun 20 orang $(40 \%)$.

\subsection{Hasil Uji Korelasi}

Didapat nilai korelasi untuk variabel keterampilan kewirausahaan diperoleh angka sebesar 0,716 yang berarti kuat, sedangkan variabel karakteristik individu angka 0,756 yang juga berarti kuat.

\subsection{Uji Asumsi Klasik 4.5.1 Uji Normalitas}

Tujuan uji normalitas adalah ingin menguji apakah dalam model regresi distribusi sebuah data mengikuti atau 


mendekati distribusi normalitas.
berdistribusi normal. Berikut ini pengujian normalitas yang didasarkan dengan uji statistik nonparametik KolmogorovSmirnov (K-S). dengan One-Sample Kolmogorov-Smirnov Test.

Tabel 1. Hasil Uji Normalitas Kolmogorov-Smirnov Test

One-Sample Kolmogorov-Smirnov Test

\begin{tabular}{|ll|r|}
\hline & & $\begin{array}{r}\text { Unstandardized } \\
\text { Residual }\end{array}$ \\
\hline N & Mean & 50 \\
Normal & Std. &, 0000000 \\
Parameters & Deviation & 2,36894735 \\
Most & Absolute &, 090 \\
Extreme & Positive &, 052 \\
Differences & Negative &,- 090 \\
Test Statistic & &, 090 \\
Asymp. Sig. (2-tailed) &, $200^{\mathrm{c}, \mathrm{d}}$ \\
\hline
\end{tabular}

a. Test distribution is Normal.

b. Calculated from data.

c. Lilliefors Significance Correction.

$\mathrm{d}$. This is a lower bound of the true significance.

Sumber: Data primer yang diolah, 2018

Berdasarkan tabel diatas terlihat bahwa nilai Asymp.Sig. (2-tailed) adalah0,200, ini berarti nilainya diatas nilai signifikan 5\% (0.05) jadi dapat disimpulkan bahwa variabel tersebut berdistribusi normal.

\subsubsection{Uji Multikolinieritas}

Dapat terlihat bahwa model regresi tidak terjadi multikolinieritas. Hal ini ditunjukan dari Nilai Tolerance untuk variabel bebas keterampilan kewirausahaan adalah $0,325>0,1$ dan, Nilai VIF untuk variabel bebas keterampilan kewirausahaan adalah 3,077 < 5 Nilai Tolerance untuk variabel bebas karakteristik individu adalah $0,325>0,1$ dan, Nilai VIF untuk variabel bebas karakteristik individu adalah 3,077 < 5. Sehingga model regresi layak dipakai untuk memprediksi keberhasilan usaha berdasarkan masukan variabel keterampilan kewirausahaan, dan variabel karakteristik individu.

\subsubsection{Uji Heteroskedastisitas}

Uji ini bertujuan untuk menguji apakah didalam model regresi terjadi ketidaksamaan varian. Jika varian dari residual satu pengamatan ke pengamatan yang lain tetap, maka disebut homoskedastisitas dan jika berbeda disebut heteroskedastisitas. Model regresi yang baik adalah yang homoskedastisitas atau tidak terjadi heteroskedastisitas. Ada beberapa cara untuk mendeteksi ada atau tidaknya heteroskedastisitas, yaitu : Analisis Grafik Dasar analisis adalah tidak ada pola yang jelas, serta titik-titik menyebar diatas dan di bawah angka 0 pada sumbu Y, maka tidak terjadi heteroskedastisitas, sedangkan jika ada pola tertentu, seperti titik-titik yang membentuk pola tertentu yang teratur, maka mengindikasikan telah terjadi heteroskedastisitas. Berdasarkan Gambar (tidak ditampilkan dalam artikel ini) terlihat bahwa tidak ada pola yang jelas,serta titik-titik menyebar diatas dan dibawah angka 0 pada sumbu Y, maka berdasarkan metode grafik tidak terjadi heteroskedastisitas pada model regresi.

\subsection{Analisis Regresi Linier Berganda}

Tabel 2. Hasil Analisis Regresi Linier Berganda

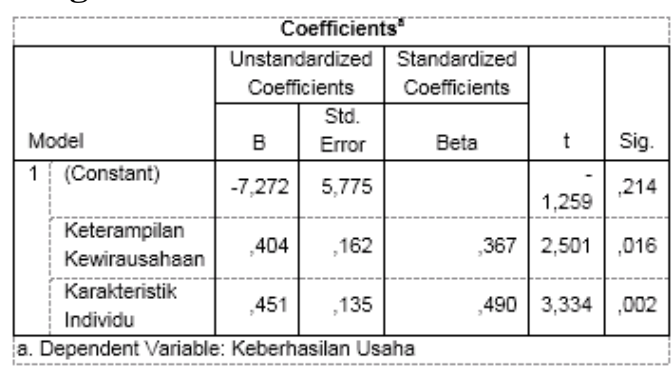

Sumber: Data primer yang diolah, 2018 
Persamaan analisis regresi linier berganda dalam penelitian ini adalah:

$$
Y=-7,272+0,404 X_{1}+0,451 X_{2}+e
$$

Persamaan diatas konstanta $(-7,272)$ dikarenakan konstanta dalam penelitian ini menghasilkan nilai negative maka nilai konstanta dianggap nol. Sedangkan untuk Koefisien $\mathrm{X}_{1}\left(\mathrm{~b}_{1}\right)=0,404$, ini berarti bahwa variabel Keterampilan Kewirausahaan $\left(\mathrm{X}_{1}\right)$ berpengaruh positif terhadap Keberhasilan Usaha, ataudengan kata lain jika Keterampilan kewirausahaan $\left(\mathrm{X}_{1}\right)$ ditingkatkan sebesar satu-satuan, maka keberhasilan usaha akan mengalami peningkatan sebesar 0,404. Koefisien $\mathrm{X}_{2}$ $\left(b_{2}\right)=0,451$, ini berarti bahwa variabel Karakteristik Individu $\left(\mathrm{X}_{2}\right)$ berpengaruh positif terhadap Keberhasilan Usaha, atau dengan kata lain jika karakteristik individu $\left(\mathrm{X}_{2}\right)$ ditingkatkan sebesar satu-satuan, maka keberhasilan usaha akan mengalami peningkatan sebesar 0,451. Koefesien bernilai positif artinya terjadi hubungan positif antara variabel karakteristik individu dengan keberhasilan usaha, semakin meningkat karakteristik individu maka akan semakin meningkat pula keberhasilan usaha pada usaha usaha mikro dan kecil di Perumahan Indogreeen.

\subsection{Uji Signifikansi Parsial (Uji t)}

Uji Signifikansi Parsial (Uji t), Pengujian ini dilakukan untuk mengetahui seberapa jauh pengaruh suatu variabel bebas secara parsial (individual) terhadap variasi variabel terikat. Hasil Uji Signifikan Parsial (Uji t) adalah : Uji t pertama, Variabel Keterampilan Kewirausahaan $\left(\mathrm{X}_{1}\right)$ : Berdasarkan hasil analisis regresi diperoleh nilai $t_{\text {hitung }}$ variabel pengetahuan kewirausahaan adalah sebesar 2,501 dan nilai $t_{\text {tabel }} 2,012$ maka $t_{\text {hitung }}>t_{\text {tabel }}(2,501>$ 2.012) dan nilai signifikansi (Sig.) 0,016 < 0,05 . Sehingga dapat disimpulkan bahwa $\mathrm{H}_{0}$ ditolak dan $\mathrm{H}_{1}$ diterima, yang artinya variabel Keterampilan Kewirausahaan $\left(\mathrm{X}_{1}\right)$ berpengaruh signifikan terhadap keberhasilan usaha (Y). Uji t kedua, Variabel Karakteristik Individu $\left(\mathrm{X}_{2}\right)$ : Berdasarkan hasil analisis regresi diperoleh nilai $t_{\text {hitung }}$ variabel karakteristik individu adalah sebesar 3,334 dan nilai $t_{\text {tabel }} 2,012$ maka $t_{\text {hitung }}>t_{\text {tabel }}(3,334>2,012)$ dan nilai signifikansi (Sig.) $0,002<0,05$. Sehingga dapat disimpulkan bahwa $\mathrm{H}_{0}$ ditolak dan $\mathrm{H}_{2}$ diterima, yang artinya variable karakteristik individu $\left(\mathrm{X}_{2}\right)$ berpengaruh signifikan terhadap keberhasilan usaha $(\mathrm{Y})$.

\subsection{Uji Signifikansi Simultan (Uji F)}

Pengujian ini dilakukan untuk melihat apakah semua variabel bebas yangdimasukkan dalam model mempunyai pengaruh secara bersama-sama terhadap variabel terikat.

Tabel 3. Hasil Uji Silmutan (Uji F)

\begin{tabular}{|c|c|c|c|c|c|c|}
\hline \multicolumn{7}{|c|}{ ANOVA } \\
\hline \multicolumn{2}{|c|}{ Model } & Sum of Squares & $d f$ & Mean Square & $F$ & Sig. \\
\hline \multirow[t]{3}{*}{1} & Regression & 559,336 & 2 & 279,668 & 47,801 &, $000^{\circ}$ \\
\hline & Residual & 274,984 & 47 & 5,851 & & \\
\hline & Total & 334,320 & 49 & & & \\
\hline \multicolumn{7}{|c|}{ a. Dependent Variable: Keberhasilan Usaha } \\
\hline & & att Kagkteris & & Denetolua & Kevirauk & \\
\hline
\end{tabular}

Sumber: Data primer yang diolah, 2018

Berdasarkan tabel uji $\mathrm{F}$ diatas dapat dilihat bahwa hasil perolehan nilai $F_{\text {hitung }}$ sebesar 47,801 dan nilai $F_{\text {tabel }}$ 3,19 maka $\mathrm{F}_{\text {hitung }}>\mathrm{F}_{\text {tabel }}(47,801>3,19)$ dan nilai signifikansi (Sig. $0,000<0,05$ ). Sehingga dapat disimpulkan bahwa H0 ditolak dan H3 diterima, yang artinya "Variabel keterampilan kewirausahaan $\left(\mathrm{X}_{1}\right)$ dan karakteristik individu $\left(\mathrm{X}_{2}\right)$ secara simultan berpengaruh terhadap keberhasilan usaha (Y)".

\subsection{Uji Koefisien Determinasi $\left(\mathbf{R}^{2}\right)$}

Hasil Pengujian koefisien determinasi

$\left(\mathrm{R}^{2}\right)$ digunakan untuk mengukur proporsi atau persentase kemampuan model dalam menerangkan variabel terikat. Koefisien determinasi berkisar antara nol sampai satu 


$\left(0 \leq \mathrm{R}^{2} \geq 1\right)$. Jika $\mathrm{R}^{2} \quad$ semakin
besar(mendekati satu), maka dapat dikatakan bahwa pengaruh variabel bebas (X) adalah besar terhadap variabel terikat (Y). Hal ini berarti model yang digunakan semakin kuat untuk menerangkan pengaruh variabel bebas terhadap variabel terikat dan demikian sebaliknya. Nilai $\mathrm{R}$ Square sebesar 0,670 berarti $67 \%$ variable keberhasilan usaha (Y) dapat dijelaskan oleh variabel keterampilan kewirausahaan $\left(\mathrm{X}_{1}\right)$, dan karakteristik individu $\left(\mathrm{X}_{2}\right)$. Sedangkan sisanya 33\% dapat dijelaskan oleh variabel-variabel lain yang tidak diteliti dalam penelitian ini.

\section{KESIMPULAN DAN SARAN}

\subsection{Kesimpulan}

Penelitian ini menghasilkan kesimpulan,:

1. Berdasarkan Uji t disimpulkan bahwa kedua variabel berpengaruh secara signifikan, dan yang paling dominan mempengaruhi keberhasilan usaha pada usaha mikro dan kecil di perumahan Indogreen adalah Karakteristik Individu $(0,451)$.

2. Berdasarkan hasil Uji $F$ dinyatakan bahwa secara simultan/bersama-sama variabel keterampilan kewirausahaan dan karakteristik individu berpengaruh terhadap keberhasilan usaha. Sehingga seluruh hipothesis (Ha) diterima dan (Ho) ditolak.

\subsection{Saran}

1. Mengingat karakteristik individu mempunyai pengaruh yang dominan terhadap keberhasilan usaha pada usaha mikro dan kecil di perumahan Indogreen, maka wirausahawan perlu lebih meningkatkan karakteristik individu, semakin meningkat karakteristik individu yang dimiliki oleh seorang wirausahawan maka akan semakin meningkat pula keberhasilan usaha yang diperolehnya.
2. Keterampilan berwirausaha para pengusaha sudah cukup baik. Hendaknya untuk mencapai tingkat yang maksimal diperlukan adanya perkembangan diri dalam berwirausaha misalnya mengikuti kegiatan pendidikan non fornal atau pelatihan mengenai kewirausahaan agar lebih teraktualisasikan potensi kewirausahaan yang dimiliki dalam menjalankan potensi usahanya. Hal ini akan menambah wawasan dan keterampilan para pengusaha dalam mengembangkan usahanya, dan bisa dijadikan acuan dalam menghadapi perdagangan yang kian kompetitif.

\section{DAFTAR PUSTAKA}

Adyas Dasmansyah, Kurniawati 2015, Faktor-Faktor yang Mempengaruhi Keberhasilan Wirausahawan. Jurnal Economicus Vol.7 No.1 Sekolah Tinggi Ekonomi Dewantara, Bogor

Anwar, Muhammad. 2014. Pengantar Kewirausahaan Teori dan Aplikasi. Ed.1.Prenadamedia Group, Jakarta..

Asep Saefullah, Sudaryono, PO Abas Sunaryo. 2011. Kewirausahaan. CV andi of set, Yogyakarta.

Cohen, L., et al. 2007. Research Methods in Education. (Sixth edition). Routledge, New York.

Dalimunthe, R. 2002. Pengaruh Karakteristik Individu, Kewirausahaan, Gaya Kepemimpinan terhadap Kemampuan Usaha serta Keberhasilan Usaha Industri Kecil Tenun dan Bordir di Sumatra Utara, Sumatra Barat dan Riau [disertasi]. Program Pascasarjana Universitas Airlangga, Surabaya.

Ghozali, Imam. 2011. Aplikasi Analisis Multivariate Dengan Program IBM SPSS 19. Edisi 5. Badan Penerbit Universitas Diponegoro, Semarang. 
Gibson et al. 2000. Organisasi. Jilid 1dan 2.

Ahli bahasa Agus Dharma, Erlangga, Jakarta.

Hasibuan, Malayu S.P. 2009. Manajemen Sumber Daya Manusia. PT. Bumi Aksara, Jakarta.

Hendro. 2011. Dasar - Dasar Kewirausahaan. Erlangga, Jakarta.

Hutagalung, Raja Bongsu dan Situmorang, Syafrizal Helmi. 2008. Pengantar Kewirausahaan, USU press, Medan.

Ina Primiana. 2009. Menggerakkan sektor riil UKM \& industri. Alfabeta, Bandung.

Kao, Raymond W.Y.; Liang, Tan Wee. 2001. Entrepreneurship and Enterprise Development in Asia. Prentice Hall Int. Inc, Singapore.

Kasmir. 2009. Kewirausahaan. PT Raja Grafindo Persada, Jakarta.

Mathieu, J. E., \& Zajac, D.M. 1990.A review and meta analysis of the antecedents, correlates, consequences of organizational commitment. Psychological bulletin.

Noor, Henry Faizal. 2007. Ekonomi Manajerial. Raja Grafindo Persada, Jakarta.

Rivai, Veithzal. 2006. Manajemen Sumber Daya Manusia untuk Perusahaan: dari Teori Ke Praktik. Edisi Pertama. PT. Raja Grafindo Persada, Jakarta.

Robbins, Stephen. P. 2006. Perilaku organisasi. Edisi Bahasa Indonesia. PT Indeks Kelompok Gramedia, Jakarta.

Salam, Burhanuddin. 2003. Logika materiil filsafat ilmu pengetahuan. Rineka Cipta. 